\title{
QUAL PODE SER O PAPEL DO DIREITO FUNDAMENTAL DA IGUALDADE EM UMA POLÍTICA DE COTAS RACIAIS?
}

MARIANA BARBOSA CIRNE ${ }^{1}$

\begin{abstract}
RESUMO: Este ensaio pretende estudar o princípio da igualdade, e a discussão concreta da política de quotas raciais como mecanismo de acesso às universidades. Sob esse tema, pretende-se aprofundar a característica abstrata do princípio da igualdade, em suas diversas possibilidades de interpretação. Apropriando-se da experiência do constitucionalismo americano e francês, espera-se pensar qual a importância de inserir direitos como a igualdade no texto constitucional. Em uma perspectiva sistêmica, almeja-se se pensar a igualdade no contexto moderno e complexo, para então conferir nova leitura aos direitos fundamentais. Após esse itinerário, busca-se retornar à questão central - cotas raciais como critério de acesso universitário - para repensar o tema em uma nova perspectiva.

PALAVRAS-CHAVE: Raça; Universidade; Igualdade.

ABSTRACT: This paper aims to study the principle of equality and a concrete discussion of the policy of racial quotas as a mechanism for access to universities. Under this theme, we intend to deepen the abstract characteristic of the principle of equality in its various possibilities of interpretation. Appropriating the experience of American and French Constitutionalism, this work expected to consider the importance of including rights such as equality in the Constitution. From a systemic perspective, it aims to think about equality in the modern and complex context, and then give a new reading of fundamental rights. After this journey, we seek to return to the central issue racial quotas as a criterion for access to university - to rethink the issue in a new perspective.

KEYWORDS: Race; University Equality.
\end{abstract}

Artigo recebido em 23.04.2011. Pareceres emitidos em 16.10.2011, 16.08.2011 e 07.02.2012. Artigo aceito para publicação em 12.03.2012.

${ }_{1}$ Bacharel em Direito pela Universidade Federal de Pernambuco (UFPE), Especialista em Direito Constitucional pela Universidade Potiguar (UNP) e em Processo Civil pelo Instituto Brasiliense de Direito Público (IDP). Mestre em Direito pela Universidade de Brasília (UNB), com área de concentração em Direito, Estado e Constituição e vinculação à linha de Pesquisa "Constituição e Democracia: Teoria, História, Direitos Fundamentais e Jurisdição Constitucional". Professora da Graduação em Direito da Universidade de Brasília - DF. Procuradora Federal e Coordenador do Centro de Estudos Jurídicos da Presidência (CEJ). marianabcirne@gmail.com e mariana.cirne@agu.gov.br 
SUMÁRIO: Introdução; 1 As Cotas Raciais como Critério de Acesso à Universidade; 2 Os Direitos Fundamentais e a Experiência das Constituições Americana e Francesa; 3 A Abertura do Princípio da Igualdade; 3.1 Uma Possível Leitura dos Direitos Fundamentais - Abertura para um Futuro; 4 Uma Possível Interpretação sobre Cotas Raciais; Conclusão.

SUMMARY: Introduction; 1 Assessments as Racial Criteria for Access to the University; 2 Fundamental Rights and the Experience of American and French Constitutions; 3 The Meaning of the Principle of Equality; 3.1 One Possible Reading of Fundamental Rights - Opening for a Future; 4 A Possible Interpretation of Racial Quotas; Conclusion.

\section{INTRODUÇ̃̃o}

\section{Crianças Negras}

Para cantar a angústia das crianças! Não das crianças de cor de oiro e rosa, Mas dessas que o vergel das esperanças Viram secar, na idade luminosa.

Das crianças que vêm da negra noite, Dum leite de venenos e de treva,

Dentre os dantescos círculos do açoite, Filhas malditas da desgraça de Eva.

Cruz e Souza

"Não podemos deixar de mencionar, ainda, que para a concretização das cotas raciais na UNB está-se promovendo verdadeiro massacre ao princípio da igualdade e da pessoa humana, na medida em que se institucionalizou um Tribunal Racial para distinguir quem é negro no Brasil." A afirmação acima transcrita, feita pelo Partido Democratas na petição inicial da ADPF $n^{\circ} 186$, sugere que a política de cotas do vestibular da Universidade de Brasília (UnB) é um massacre ao princípio da igualdade. Essa é uma forma de ver a questão.

De outra parte, existem trabalhos que endossam exatamente o contrário, para concluir que as cotas raciais, ao "garantir o respeito ao princípio da igualdade, ou, melhor dizendo, a discriminação efetivada por tais políticas deve representar a efetivação, em concreto, daquele princípio abstratamente previsto na Constituição." ${ }^{3}$ Logo, pautados também na igualdade, há estudos que afirmam ser a política de cotas a materialização em concreto deste princípio.

${ }^{2}$ Petição inicial dos Democratas. Disponível em: http://redir.stf.jus.br/estfvisualizadorpub/jsp/ consultarprocessoeletronico/ConsultarProcessoEletronico.jsf?seqobjetoincidente=2691269. Acesso em 06.09.2010.

${ }^{3}$ AZEVEDO, Damião Alves de. A Justiça e as Cores: a possibilidade de adequação constitucional de ações afirmativas voltadas para negros e indígenas no ensino superior. Dissertação de mestrado. Faculdade de Direito da Universidade de Brasília, 2007, p. 26. 
Ao notar que ambas as posições - contrária e favorável à política de cotas raciais - se pautam no mesmo princípio, parece a este ensaio essencial perguntar: afinal, de que lado está o princípio da igualdade?

No intuito de problematizar essa afirmação, e pôr em destaque a discussão sobre o sistema de cotas raciais, parece necessário questionar qual é o conteúdo do princípio da igualdade? Tal princípio admite políticas públicas como a de cotas raciais para o acesso de alunos negros na universidade? As cotas são mecanismos aptos a ensejar um tratamento mais igualitário na sociedade brasileira?

Exatamente sobre tais questões é que este trabalho pretende se debruçar.

O pano de fundo eleito para a discussão deste estudo, como demonstram as citações iniciais, será a política de cotas raciais para o acesso à universidade que merecerá breve explicação no primeiro tópico deste trabalho.

No intuito de (re) pensar o conceito de um princípio aberto como o da igualdade, pretende-se reconstruir neste estudo uma noção do constitucionalismo americano e francês interligada com o processo de constitucionalização dos direitos fundamentais. Espera-se tentar compreender, naquele contexto, qual foi - e ainda pode ser - a importância do ato de se incluir os direitos fundamentais no corpo de uma constituição.

O próximo passo será apresentar os princípios fundamentais como conceitos abstratos, que apresentam grandes desafios quando se busca aplicá-los no caso concreto. A discussão aqui se centra em como tratar todos com igualdades, em uma sociedade tão rica em diversidade. Para apresentar esse problema, Jeremy Waldron parece conferir uma boa noção dessa contradição, a ensejar uma importante reflexão sobre o tema.

Mas, no intuito de encontrar um papel mais interessante aos direitos fundamentais - e em especial à igualdade - no tópico seguinte se adentrará na perspectiva de Giancarlo Corsi, que se utiliza de um trabalho de Niklas Luhmann para desenvolver uma visão diferente de se pensar o papel dos direitos fundamentais. A proposta é inserir na discussão a complexidade trazida pela modernidade e buscar ver o que a sociologia do direito, por meio da teoria dos sistemas, pode ajudar na tarefa de desvendar os direitos fundamentais.

Após transcorrer esse percurso, espera-se reabrir a discussão sobre as cotas raciais com outros olhos, para enfrentar a querela sobre o princípio da igualdade em outra perspectiva e quem sabe propor uma nova maneira de pensar a igualdade racial.

\section{AS COTAS RACIAIS COMO CRITÉRIO DE ACESSO À UNIVERSIDADE}

O primeiro registro brasileiro sobre a política de cotas, no âmbito legislativo, é o Decreto Legislativo $\mathrm{n}^{\circ} 23$, de 21.06.1967, que deu caráter normativo à Convenção Internacional para eliminação de todas as formas de 
discriminação racial, admitindo as ações afirmativas raciais. ${ }^{4}$ Outro exemplo de iniciativa legal foi o Decreto Presidencial $n^{\circ} 1.9904 / 96$, que introduziu a política nacional de direitos humanos no Brasil. ${ }^{5}$ Mais recente, pode-se citar a Lei $n^{0}$ 10.558/02, intitulada de "Diversidade na Universidade", que também estimula políticas como a de cotas raciais. Todas essas leis - apesar de tratarem de tempos diversos - têm como elemento comum o intuito de reduzir as desigualdades raciais.

Como já anunciado, essas normas pretendem em verdade incentivar políticas a serem implementadas por iniciativa das universidades. Isso porque, as universidades, diante de seu atributo de autonomia universitária ${ }^{6}$, podem ser um dos instrumentos de combate ao racismo ao decidir propor um sistema de $\operatorname{cotas}^{7}$ de acesso a depender de cada um de seus contextos sociais $^{8}$. Em muitos desses casos - como é exemplo a UnB - o critério para o acesso diferenciado eleito foi o da raça ${ }^{9}$.

${ }^{4}$ Cf. PISCITELLI, Rui Magalhães. O Estado como Promotor de Ações Afirmativas e a Política de Cotas para o Acesso dos Negros à Universidade. Curitiba: Juruá, 2009, p. 120. Outro exemplo dado pelo autor é o da Lei $\mathrm{n}^{\circ} 5.465 / 68$, chamada "Lei do Boi", que reservava $50 \%$ das vagas nas escolas superiores de agricultura e veterinária para filhos de proprietários rurais.

${ }^{5}$ Idem, p. 121.

${ }^{6}$ Art. 207 da Constituição Federal: "As universidades gozam de autonomia didático-científica, administrativa e de gestão financeira e patrimonial, e obedecerão ao princípio de indissociabilidade entre ensino, pesquisa e extensão." Para aprofundar a discussão sobre os poderes conferidos pela autonomia à universidades, ver: LINHARES, Mônica Mansur. Autonomia Universitária no Direito Educacional Brasileiro. São Paulo: Segmento, 2005 e SAMPAIO, Anita Lapa Borges. Autonomia Universitária: um modelo de interpretação do artigo 207 da Constituição Federal. Brasília: Editora da Universidade de Brasília, 1998.

${ }^{7}$ Note-se que proposta de cotas não é política restrita às universidades e nem à questão racial. Outros exemplos, no âmbito legislativo são: a) Lei 8.112/90, que prescreve, em seu art. $5^{\circ}$, § 2, cotas de até $20 \%$ para os portadores de deficiências no serviço público civil da união; b) Lei $8.213 / 91$ que fixou em seu art. 93, cotas para os portadores de deficiência no setor privado; c) Lei 9.504/97, que prevê em seu art. 10, § 2, cotas para mulheres nas candidaturas partidárias. ${ }^{8}$ Há uma grande variedade de políticas, a depender da cada contexto das universidades. $\mathrm{Na}$ Universidade Federal de Pernambuco, por exemplo, no ano de 2011, os alunos que concluíram integral e exclusivamente os três anos do ensino médio em qualquer escola pública estadual ou municipal do Estado receberão o incremento de $10 \%$ em seu argumento de classificação. Para aqueles que concorram a uma vaga nas unidades de Vitória de Santo Antão ou do Agreste, e tenham concluído os três anos do ensino médio em escola do interior do Estado de Pernambuco terão um acréscimo de $5 \%$ na sua classificação. Aqui a preocupação centra-se na disparidade regional. UNIVERSIDADE FEDERAL DE PERNAMBUCO. Admissão de Alunos. Disponível em: http://www.ufpe.br/proacad/index.php?option=com content\&view= article\&id=72\&ltemid=140. 2010. Acesso em 10.07.2010. No caso da Universidade Federal do Tocantins, diante da realidade de que $62 \%$ dos alunos se declararam negros ou pardos, decidiu-se que desde 2004 apenas $5 \%$ de suas vagas serão reservadas para indígenas. UNIVERSIDADE FEDERAL DO TOCANTINS. Vestibular. Disponível em: http://uww.copese.uft.edu.br/. 2010. Acesso em 10.07.2010. Apesar disso, estão em trâmite perante o Congresso Nacional projetos que pretendem tornar a definição de cotas uma política uniforme nacional. Exemplos são: PL $n^{\circ} 3.627 / 04$ (reserva de $50 \%$ das vagas para alunos provenientes de escolas públicas de ensino médio, com proporção de negros e índios) e PL n 7.200/06 (obriga ações afirmativas para os egressos de escola pública).

9 Outro interessante exemplo é da Universidade Federal do Paraná (Resolução nº 37/2004 - COUN), que reserva $20 \%$ das vagas para o critério de inclusão racial de estudantes afrodescendentes. 
No caso da UnB, que merecerá melhor estudo nesse trabalho, os atos que inseriram a política de cotas são fruto da Reunião Extraordinária do Conselho Extraordinário de Ensino, Pesquisa e Extensão da Universidade de Brasília de 06.06.2003, que deu ensejo à Resolução $n^{\circ} 38$, de 18.06.2003 do CEPE. Nos termos de tal ato, o seu objetivo é: "a) disponibilizar, por um período de 10 anos, 20\% das vagas do vestibular da Unb para estudantes negros, em todos os cursos oferecidos pela universidade." Com a implementação de tal proposta, "A Unb intensificará um processo de integração racial, étnica e social no seio da sua população discente, atualmente extremamente elitizada".

Então, a proposta aqui parece ser reduzir as desigualdades.

No entanto, em 20.07.2009, o DEM - Partido Democratas propôs uma ação de descumprimento de preceito fundamental, também escorada na igualdade, no intuito de declarar inconstitucional a política de cotas da UNB (Resolução no 38/2003/CEPE/UNB) $^{10}$.

Isso demonstra que o mesmo princípio - a igualdade - pode ser visto sob diversos ângulos, com conclusões muito divergentes. Ora, se existem posições antagônicas sobre o mesmo princípio, qual seria o sentido de princípios fundamentais como o da igualdade estar na constituição?

Diante da discussão lançada na sociedade sobre cotas raciais, que está em voga também no judiciário, parece-nos interessante resgatar algumas das noções que construíram a inserção, em constituições, de direitos fundamentais. Para essa tarefa parece-nos extremamente interessante algumas das discussões da revolução americana e francesa, como se demonstra a seguir.

\section{OS DIREITOS FUNDAMENTAIS E A EXPERIÊNCIA DAS} CONSTITUIÇÕES AMERICANA E FRANCESA

De acordo com tudo que foi dito até aqui, parece necessário questionar agora por que é tão importante inserir tais preceitos no texto de uma constituição?

Um possível caminho, como já dito, para sugerir respostas a essas perguntas seria a pesquisa do constitucionalismo, com especial atenção para as revoluções francesa e americana, no intuito de questionar o surgimento e a permanência das formas constitucionais até hoje.

Nessa tarefa, uma interessante indagação pode vir de Madison, um dos pais do constitucionalismo americano, que quando escreveu o Federalista número 10 ressaltou que a grande vantagem de uma constituição seria conter

Cf. PISCITELLI, Rui Magalhães. O Estado como Promotor de Ações Afirmativas e a Política de Cotas para o Acesso dos Negros à Universidade. Curitiba: Juruá, 2009.

${ }^{10}$ Petição Inicial dos Democratas. Disponível em: http://redir.stf.jus.br/estfvisualizadorpub/jsp/ consultarprocessoeletronico/ConsultarProcessoEletronico.jsf?seqobjetoincidente=2691269. Acesso em 06.09.2010. 
e controlar a violência das facções ${ }^{11}$. O próprio autor advertiu que muitas decisões seriam tomadas sem justiça e sem levarem em consideração os partidos minoritários, por uma maioria arrogante e interesseira.

Como proposta de solução para os malefícios das facções, Madison identificou dois possíveis processos: a) a remoção de suas causas ou b) o controle de seus efeitos. ${ }^{12}$

Quando abordou as causas das facções, Madison propôs dois possíveis remédios: a) a destruição da liberdade ou b) fazer com que todos os cidadãos tenham a mesma opinião. Contudo, em seguida, verificou que nenhuma das duas soluções era factível. A liberdade é essencial como o ar, não podendo ser retirada das facções. Por outro lado, é preciso reconhecer que sempre haverá opiniões diferentes, pois isso está na essência dos homens.

Desenvolvendo o seu raciocínio, sem deixar de reconhecer a permanência de paixões e interesses nas pessoas, Madison identificou a importância da legislação moderna para a coordenação destes interesses em choque. Contudo, conclui que isso não bastaria para remover as causas pelas quais existem facções ${ }^{13}$. Madison, então atribuiu um importante papel às constituições, mas advertiu que isso não seria suficiente para conter os interesses e paixões (as facções). No entanto, aparece aqui a constituição como importante mecanismo para lidar com os riscos de uma sociedade de homens.

Endossando tal raciocínio, Antônio Negri, quando analisa a experiência da constituição americana, citando as premissas de Madison, pensa 0 constitucionalismo com os seguintes temperamentos:

Se os homens fossem anjos, não haveria necessidade de governo; se os homens fossem governados por anjos, nenhum controle, externo ou interno, sobre o governo seria necessário. Porém, quando se organiza um governo que será exercido por homens sobre outros homens, a grande dificuldade será, primeiro, pôr o governo em condições de controlar os governados e, segundo, obrigá-los a controlar a si próprio. $^{14}$

\footnotetext{
${ }^{11} \mathrm{O}$ autor define as facções como "um grupo de cidadãos, representando quer a maioria, quer a minoria do conjunto, unidos e agindo sobre um impulso comum de sentimentos ou de interesses contrários aos direitos dos outros cidadãos ou aos interesses permanentes e coletivos da comunidade." Cf. MADISON, James. Federalista $n^{0} 10$ e $n^{0} 51$. In: . HAMILTON, Alexander; JAY, Jonh. O Federalista. Trad. Heitor Almeida Herrera. Brasília: Universidade de Brasília, 1984, p. 148

${ }^{12}$ Idem.

${ }^{13}$ MADISON, James. Federalista $n^{\circ} 10$ e $n^{0} 51$. In: HAMILTON, Alexander; JAY, Jonh. O Federalista. Trad. Heitor Almeida Herrera. Brasília: Universidade de Brasília, 1984, p. 150.

14 NEGRI, Antônio. O Poder Constituinte. Ensaio sobre as Alternativas da Modernidade. Trad. Adriano Pilatti. Rio de Janeiro: DP\&A, 2002, p. 245.
} 
Horst Dippel, ao avaliar a história do constitucionalismo americano, explica que apesar da diversidade ${ }^{15}$ entre as constituições dos Estados americanos só com a promessa de juntar à constituição uma declaração de direitos se assegurou a ratificação da constituição de 1787/1788. Mas, ressalta que na ideia americana a inclusão de direitos pretendia servir ao seu exercício em ações judiciais. Nesse primeiro momento, as declarações de direitos americanas foram marcadas pela pretensão de evitar "as exposições extensas de direitos elevados mas destituídos de conseqüências jurídicas significativas"16, para atribuir aos indivíduos "direitos suscetíveis de serem exercidos, por meio de ações judiciais ${ }^{17}$, contra intromissões do governo com o fim de assegurar ao indivíduo a proteção dos seus direitos e a benção da liberdade" 1819 .

Por sua vez, sobre a experiência Francesa, Dippel aduz que a proteção não se voltou para ações no judiciário, mas sim para o cumprimento pelo Estado, em suas condutas, dos princípios democráticos e do rule of law. Na França, os debates não se centraram nos indivíduos e seus direitos, mas sim na Teoria do Estado e do seu Poder. ${ }^{20}$

No transcurso da história da constitucionalização de direitos americana, os direitos ativos ${ }^{21}$ assumem, entre 1832 e 1849, a posição de protagonistas. Neste processo, as proteções de processo penal ganham enorme destaque. Mas, desse processo evolutivo do direito parece interessante chamar atenção

\footnotetext{
${ }^{15}$ Segundo o autor, nos Estados Unidos, no período de 1776 a 1849 foram projetadas 78 constituições. Sendo que 21 nunca foram colocadas em prática e 10\% não continham qualquer referência a direitos humanos. Cf. DIPPEL, Horst. Os Direitos Humanos na América, 1776-1849: redescobrindo o contributo dos Estados. In: História do Constitucionalismo Moderno Novas Perspectivas. Trad. António Manuel Hespanha e Cristina Nogueira da Silva. Lisboa: Calouste Gulbenkian, 2007. No mesmo sentido, Lynn Hunt afirma que na independência americana "embora nem todos concordassem sobre a importância de declarar os direitos, ou sobre o conteúdo dos direitos a serem declarados, a independência abriu a porta para a declaração dos direitos." HUNT, Lynn. "Eles deram um grande exemplo": declarando os direitos. In: A Invenção dos Direitos Humanos - Uma História. Trad. Rosaura Eichenberg. São Paulo: Companhia das Letras, 2009, p. 122.

${ }^{16}$ Op. Cit. p. 189.

${ }^{17}$ Apesar de supostamente se referirem a demandas judiciais, o próprio Dippel afirma que tais determinações eram "mais a do apelo moral do que a de uma determinação jurídica destinada a servir de fundamento a acções judiciais contra o governo". Recordam uma espécie de súplica ao Rei. Cf. Op Cit., p. 200.

${ }^{18}$ Op. Cit., p. 200. Lynn Hunt afirma que "era um documento profundamente particularista que protegia os cidadãos americanos contra abusos cometidos pelo governo federal. Cf. HUNT, Lynn. "Eles deram um grande exemplo": declarando os direitos. In: A Invenção dos Direitos Humanos - Uma História. Trad. Rosaura Eichenberg. São Paulo: Companhia das Letras, 2009, p. 126.

${ }^{19}$ A Bill.

${ }^{20}$ Op. Cit., p. 229.

${ }^{21}$ Quando trata desse período, Dippel afirma que "Estes direitos activos foram obviamente mais importantes do que a protecção passiva de direitos". Segundo a sua pesquisa, nessas declarações os direitos ativos ultrapassam os de proteção passiva em cerca de 60 a $80 \%$. Op. Cit. p. 208.
} 
para o fato que não houve uma preocupação sobre a mudança do nome de direitos. "Não se ambicionava inventar, para cada ocasião, uma nova expressão para designar um direito de há muito estabelecido e suficientemente conhecido" 22 . E isso é extremamente interessante, como explica o autor:

O seu mérito, contudo, é que aquele método facilita o reconhecimento de direitos homogêneos e revela facilmente até as menores divergências. A permanência de direitos torna-se facilmente notada e as incertezas sobre o conteúdo são minimizadas, ou, enquanto compromissos políticos, deixadas em aberto para serem posteriormente desenvolvidas. ${ }^{23}$

Lynn Hunt, por sua vez, quando trabalha sobre essa universalidade dos conceitos, no contexto do constitucionalismo francês, aduz que "nenhum dos artigos da declaração especificava os direitos de grupos particulares". ${ }^{24}$ As classes, as religiões e os sexos não apareciam na declaração, pois naquele momento era tudo ou nada. Nota-se, do que se extrai das conclusões de tais autores que o constitucionalismo de direitos abstratos sem a particularização de grupos e dos casos concretos - tornou possível a união da França e dos Estados Unidos em uma só pretensão de efetivar direitos fundamentais. E essa experiência pode nos ser muito importante para compreender o constitucionalismo moderno.

Eis aqui uma das perspectivas a que se pretende desenvolver neste trabalho: a abertura dos direitos fundamentais. Mas, não basta essa construção histórica, devendo-se também apontar a importância de se afirmar ${ }^{25}$ esses direitos. Não fosse suficiente o caráter aberto dos direitos fundamentais, Lynn Hunt adverte que "apesar de sua importância, o ato de declarar não resolvia todas as questões" ${ }^{26}$. Como a autora explica, as declarações de 1776 e 1778 abriram panoramas políticos inteiramente novos ${ }^{27}$. Pode-se resumir assim esse desafio:

\footnotetext{
${ }^{22}$ DIPPEL, Horst. Os Direitos Humanos na América, 1776-1849: redescobrindo o contributo dos Estados. In:__. História do Constitucionalismo Moderno - Novas Perspectivas. Trad. António Manuel Hespanha e Cristina Nogueira da Silva. Lisboa: Calouste Gulbenkian, 2007, p. 221.

24 HUNT, Lynn. "Eles deram um grande exemplo": declarando os direitos. In: A Invenção dos Direitos Humanos - Uma História. Trad. Rosaura Eichenberg. São Paulo: Companhia das Letras, 2009, p. 132.

${ }^{25}$ Sobre o papel de declarar diretos, usando a ideia da declaração de independência americana, Jacques Derrida trabalha o seu sentido perfomativo, para explicar que "The signature invents the signer." Cf. DERRIDA, Jacques. Declarations of Independence. In: __. Negotiations: interventions and interviews (1971-2001). Stanford: Stanford University Press, 2002, p. 49.

${ }^{26}$ Op. Cit., p. 133. Segundo Hunt, o ato de declarar prestava mais urgência a certas questões (como propriedade e minorias religiosas) além de abrir novas questões de grupos (posição social dos escravos e das mulheres.

${ }^{27}$ HUNT, Lynn. "Eles deram um grande exemplo": declarando os direitos. In: A Invenção dos Direitos Humanos - Uma História. Trad. Rosaura Eichenberg. São Paulo: Companhia das Letras, 2009, p. 114.
} 
'A ação de afirmar, dizer, apresentar ou anunciar aberta, explícita ou formalmente', implícita no ato de declarar, tinha uma lógica própria. Uma vez enunciados abertamente, os direitos propunham novas questões - questões antes não cogitadas e não cogitáveis. O ato de declarar os direitos revelou-se apenas o primeiro passo num processo extremamente tenso que continua até os nossos dias.

Exatamente sobre esse desafio que nasce no ato de declarar os direitos fundamentais é que se pretende trabalhar os direitos fundamentais no próximo tópico. Para tanto, serão trazidos para a discussão as seguintes perguntas: Os direitos fundamentais são abertos em seu conteúdo? Qual pode ser o sentido dessa abertura?

\section{A ABERTURA DO PRINCÍPIO DA IGUALDADE}

A Constituição brasileira de 1988 tem no princípio da igualdade um dos seus principais pilares ${ }^{28}$, quando afirma no início do capítulo em que inicia o título sobre "os direitos e deveres fundamentais", o seguinte:

Art. $5^{\circ}$ Todos são iguais perante a lei, sem distinção de qualquer natureza, garantindo-se aos brasileiros e aos estrangeiros residentes no País a inviolabilidade do direito à vida, à liberdade, à igualdade, à segurança e à propriedade, nos termos seguintes: (grifo nosso)

Mas, parece que o grande desafio que persiste à leitura do artigo é saber em que medida essa igualdade, em uma comunidade tão plural como o Brasil, é possível. Quais os seus parâmetros? A mesma lei deve albergar todos?

Sabe-se que a desigualdade fática pode gerar um sentimento de descrença no princípio da igualdade. Tanto é assim que, em um trabalho sobre o tema, Fábio Konder Comparato questionou "o reconhecimento incontestável, nos dias que correm, de que os homens nascem iguais, em dignidade e direitos, mas vivem, frequentemente, em situações da mais escandalosa desigualdade quanto às condições sócio-econômicas básicas (educação, saúde, habitação, trabalho, previdência), não estaria a indicar que o velho princípio da isonomia acabou sendo superado na prática?"

Bem, como se demonstrará, esse trabalho não aceita tal premissa.

Quando trata sobre o conceito de Estado de Direito, Jeremy Waldron explora a nossa ingênua noção de igualdade, sem quaisquer exceções. Diz: "Our belief in the rule of law commits us to the principle that the Law should be the same for everyone: one law for all and no exception."29

\footnotetext{
${ }^{28}$ Note-se que além de contar no artigo $5^{\circ}$ da CF, já transcrito, o princípio da igualdade também está inserto no preâmbulo constitucional, e especificamente quanto à universidade, na igualdade de acesso inserta no art. 206, I, da Constituição Federal.

${ }_{29}$ WALDRON, Jeremy. One Law for all? The Logic of Cultural Accommodation. In: 59 Washington and Lee Law Review 2002, p. 3.
} 
Eis aqui a ideia ilusória de que todos podem receber tratamento idêntico, sem exceções.

Contudo, logo em seguida, o próprio Waldron desconstrói a sua primeira afirmação, para afirmar que "At the same time, we live in a society in which there are many different cultures and bewildering variety of religions and belief systems, each capable of attributing peculiar significance to the actions and circumstances in which the law of the land is interested." ${ }^{30} \mathrm{Em}$ outras palavras, chama a nossa atenção para as nossas diferenças e para a possibilidade de um mesmo gesto ter sentidos diversos, a depender do seu contexto ${ }^{31}$.

Então, diante de cada contexto, "laws have all sorts of exceptions, conditions, and qualifications" ${ }^{\prime \prime 2}$. Mas, nem sempre essa distinção será tão simples de ser feita. Então, diante das exceções, parece-nos possível ver o quanto o estratagema da lei pode ser falível. ${ }^{33}$ Ao mesmo tempo em que se defende a não aplicação da "zero-tolerance" (aplicação cega da lei, sem qualquer exceção), não se espera que se admitam exceções para favorecer certos grupos. "Them seems to be the worst of both words"34.

Não se pode esquecer que admitir exceções, em uma regra geral de um princípio, pode também nos impor um número incrível de dificuldades. Então, em seguida Waldron decide trabalhar com essas dificuldades, pautado nas diferenças culturais e religiosas ${ }^{35}$. No entanto, para o que se pretende estudar neste trabalho (a questão racial), parece-nos interessante entender que os princípios, aceitam sim escusas e que seus conceitos podem ser abertos, sem, contudo isso retirar todo o seu sentido.

Uma proposta interessante de leitura dos diretos fundamentais em especial do da igualdade para o exemplo em estudo - parece se apresentar de uma reflexão de Giancarlo Corsi, quanto ao seu papel no constitucionalismo moderno.

\footnotetext{
${ }^{30}$ Op. Cit., p. 4.

${ }^{31}$ Para ilustrar sua afirmação Waldron narra casos como o de, por um lado, um adulto que dá álcool a uma criança e por outro, o uso do vinho, pelo padre, na comunhão espiritual de um jovem. E questiona se podem ser os dois casos vistos da mesma maneira. "Because the law is oriented toward cutural meaning in that way, it surely should be open to the possibility that the same behavior (with the same body parts) might have a quite different cultural meaning to those who only just now are becoming acquainted with American's sexual obsessions". Cf. WALDRON, Jeremy. One Law for all? The Logic of Cultural Accommodation. In: 59 Washington and Lee Law Review 2002, pp. 4-7.

32 WALDRON, Jeremy. One Law for all? The Logic of Cultural Accommodation. In: 59 Washington and Lee Law Review 2002, p. 4.

${ }^{33}$ Op. Cit. p. 6

${ }^{34}$ Op. Cit. p. 9.

35 No tópico seguinte, Waldron se aprofunda na discussão sobre "individualized justice" para discutir o julgamento do indivíduo dentro de seu contexto, respeitando-se assim a diversidade cultural. Mas, logo em seguida, o próprio autor questiona se devemos manter, em todo caso, esse mosaico de diversidade? Cf. Op. Cit. p. 11-13.
} 
3.1 Uma Possível Leitura dos Direitos Fundamentais - Abertura para um Futuro

Uma interessante proposta de leitura dos direitos fundamentais é sugerida por Giancarlo Corsi em seu texto "Sociologia Jurídica",36. Partindo de premissas do trabalho de Niklas Luhmann, em "A Constituição como aquisição evolutiva do direito",37, Corsi pretende explicar a constituição como acoplamento estrutural entre os subsistemas do direito e da política ${ }^{38}$ e por meio da teoria dos sistemas defende que seria viável ver a constituição como a abertura para um futuro incerto.

Para alcançar essas conclusões, Giancarlo Corsi explica que a sociologia pouco se debruçou sobre o direito ${ }^{39}$, afinal a pesquisa empírica poderia desvelar o que se pode perceber com grande facilidade: o quanto o direito é pouco justo e o quanto os seus princípios são desrespeitados ${ }^{40}$. No entanto, é exatamente em tais pontos que se pode vislumbrar um campo para a crítica ao direito, ao se buscar estranhezas naquilo que parece normal.

Diante de tal nova visão, Corsi defende que merece questionamento o que é mais surpreendente ${ }^{41}$ : "o fato de os princípios fundamentais da modernidade sejam completamente desrespeitados na realidade social efetiva ou, ainda, o fato de a sociedade atual se identifique, radicalmente, mediante indeterminações semânticas tais como os valores, ao ponto de

36 CORSI, Giancarlo. "Sociologia da Constituição". Revista da Faculdade de Direito da Universidade Federal de Minas Gerais. Trad. Juliana Neuenschwander Magalhães. No 39. Belo Horizonte: jan./jun. 2001.

${ }^{37}$ LUHMANN, Niklas. "A Constituição como Aquisição Evolutiva". Trad. de Menelick de Carvalho Netto (para fins acadêmicos). In: ZAGREBELSKY, Gustavo; PORTINARO, Píer Paolo; LUTHER, Jörg (Orgs.). Il Futuro della Constituzione. Torino: Einaudi, 1996.

${ }^{38}$ Segundo Niklas Luhmann : "A relação entre o sistema político e o jurídico assemelha-se mais com a das bolas de bilhar que, apesar da contínua freqüência com que se entrechocam, cada uma continua a percorrer o seu caminho separado, do que com a de gêmeos siameses somente capazes de se moverem conjuntamente. Na concepção moderna, a base da realidade das Constituições consiste na diferenciação funcional do sistema social." Op. Cit., p. 25.

39 Sobre essas dificuldades, Niklas Luhmann na introdução do livro Sociologia do Direito questiona: "por que a sociologia do direito é tão difícil para os sociólogos?". Como possíveis respostas arrola: o nível de complicação extraordinário do direito, a dificuldade de isolar o direito em termos empíricos, dentre outros. Mas, propõe como alternativa possível à sociologia pesquisar o papel do jurista, ou dos colegiados de juízes ou sobre as opiniões sobre o direito. Cf. LUHMANN, Niklas. Sociologia do Direito 1. Trad. Gustavo Bayer. Rio de Janeiro: Edições Tempo brasileiro, 1983, pp. 7-11. Segundo Cristiano Paixão, o desafio crucial da sociologia moderna para Luhmann é "abarcar a complexidade de um mundo socialmente contingente" Cf. PINTO, Cristiano Paixão Araujo. Modernidade, tempo e direito. Belo Horizonte: Del Rey, 2002, p. 173.

40 CORSI, Giancarlo. "Sociologia da Constituição". Revista da Faculdade de Direito da Universidade Federal de Minas Gerais. Trad. Juliana Neuenschwander Magalhães. No 39 . Belo Horizonte: jan./jun. 2001, p. 1.

${ }^{41}$ Para chegar a tal estranhamento, Giacarlo Corsi propõe como um dos possíveis critérios para construir objetos de pesquisa a improbabilidade de certas estruturas. Por esse mecanismo, encontra tal questionamento. Cf. CORSI, Giancarlo. "Sociologia da Constituição". Revista da Faculdade de Direito da Universidade Federal de Minas Gerais. Trad. Juliana Neuenschwander Magalhães. № 39. Belo Horizonte: jan./jun. 2001, p. 2. 
inseri-los nas constituições". ${ }^{42}$ E mais interessante a este trabalho seria o seguinte questionamento, formulado por Corsi: "O que é mais estranho, que o ideal da igualdade não encontre correspondência na realidade ou que uma sociedade incrivelmente heterogênea identifique-se com tal princípio?"43

Para tentar responder essa pergunta, o autor oferece como proposta interessante buscar compreender quais ideias são produzidas em uma sociedade estruturada de forma moderna. Em outras palavras, a sugestão de Giancarlo Corsi é observar a constituição de uma perspectiva sociológica. Para essa refutação, começa com o questionamento dos juristas sobre o que é a constituição, e as respostas, que seriam parcialmente heterogêneas, mas certamente compartilhariam a noção de que "marca a imposição do direito positivo sobre o direito natural, porque vincula de forma completa o poder $^{44}$ e, também, porque é universal".

E o que parece mais interessante é que "em poucas décadas as constituições tornaram-se um instrumento de garantia e de "fundamento" (seja jurídico, seja político) quase natural: parece que este é o resultado de um longo processo histórico". ${ }^{45}$ Mas, para a sociologia, o problema não é só histórico, mas também evolutivo, afinal a constituição é "uma aquisição evolutiva que responde a condições sócio culturais que, no arco de pouco mais de um século, transformaram-se profundamente". Eis aqui a transformação que a constituição viveu, para transformar, e (re)transformar o seu conteúdo. Sobre essa questão, Niklas Luhmann:

Os juristas, conquanto tendam a considerar as Constituições mais como objeto de uma construção planejada, encontram-se hoje dispostos a admitir que essa construção não pode ser um processo único, que tenha acontecido de uma só vez, mas que, ao contrário, deve ser posteriormente replanejado através da interpretação e eventualmente através de mutação constitucionais. Os sociólogos tendem a redimensionar mais o momento da criação intencional e, com um certo respeito (não sem indulgência), tendem a considerá-lo como uma ilusão da factibilidade. Daí serem compelidos a teorizar, a conceptualizar, em uma perspectiva de teoria da evolução. ${ }^{46}$

\footnotetext{
${ }^{42}$ Op. Cit., p. 2.

${ }^{43}$ Op. Cit. p. 2.

44 Trazendo tais premissas ao contexto brasileiro, interessante a definição de José Afonso da Silva sobre a constituição: "A constituição é o conjunto de normas que organiza os elementos constitutivos do Estado". Cf. SILVA, José Afonso da. Curso de Direito Constitucional Positivo. São Paulo: Malheiros, 2002, p. 38. Outro exemplo é o de Uadi Lammêgos Bulos, quando afirma que "as constituições revelam a particular maneira de ser do Estado" Cf. BULOS, Uadi Lammêgos. Curso de Direito Constitucional. São Paulo: Saraiva, 2009, p. 29.

45 CORSI, Giancarlo. "Sociologia da Constituição". Revista da Faculdade de Direito da Universidade Federal de Minas Gerais. Trad. Juliana Neuenschwander Magalhães. № 39. Belo Horizonte: jan./jun. 2001, p. 2.

${ }^{46}$ LUHMANN, Niklas. "A Constituição como Aquisição Evolutiva". Trad. de Menelick de Carvalho Netto (para fins acadêmicos). In: ZAGREBELSKY, Gustavo; PORTINARO, Píer Paolo; LUTHER, Jörg (Orgs.). Il Futuro della Constituzione. Torino: Einaudi, 1996, p. 2.
} 
A sociologia caracteriza a modernidade ${ }^{47}$ como elemento que transformou drasticamente as relações do direito com as diferenças sociais e com as perspectivas temporais. $\mathrm{E}$ a sua modificação substancial reside na relação entre o direito e seus fundamentos. Em outras palavras, pergunta-se: a constituição é o fundamento do direito?

Para Corsi e Luhmann $^{48}$ a constituição, se vista sob a perspectiva sociológica, leva o seu conceito para um caminho diverso do fundamento ou vinculo último do direito. Considera-se a constituição como "acoplamento ${ }^{49}$

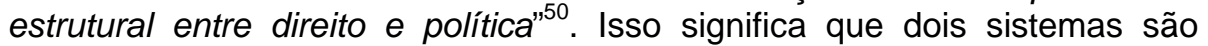
completamente autônomos e, mediante uma estrutura comum (no caso, a constituição), especificam de modo extremamente circunscrito e seletivo as possibilidades de "se irritarem" reciprocamente. Analisando esse processo Luhmann esclarece que "o conceito de Constituição, contrariamente ao que parece à primeira vista, é uma reação à diferenciação entre direito e política, ou dito com uma ênfase ainda maior, à total separação de ambos os sistemas de funções e à consequente necessidade de uma religação entre eles." ${ }^{51}$

E por que isso é importante? Porque a invenção da constituição é uma reação à diferenciação moderna entre o direito e a política e uma tentativa de resolver os seus problemas. Os seus paradoxos ${ }^{52}$. São eles os paradoxos do soberano e o do direito. E para ocultar esses paradoxos ${ }^{53}$, a constituição transfere o peso de um sistema para o outro "a soberania é transferida, da posição de vértice na hierarquia social para o povo, encontrando sua legitimação no vínculo jurídico constitucional; o direito, por sua vez, remete

${ }^{47}$ Sobre a complexidade da modernidade, e sua importância para a teoria de Niklas Luhmann, Cf. PINTO, Cristiano Paixão Araujo. Modernidade, Tempo e Direito. Belo Horizonte: Del Rey, 2002, pp. 2140-238.

${ }^{48}$ Segundo Niklas Luhmann: "A interpretação jurídica justifica a necessidade da Constituição com a necessidade de se fundar a validade do direito. Mas essa afirmação não faz mais do que nos levar a posteriormente questionar a fundamentação da validade do direito constitucional. Cf. LUHMANN, Niklas. "A Constituição como Aquisição Evolutiva". Trad. de Menelick de Carvalho Netto (para fins acadêmicos). In: ZAGREBELSKY, Gustavo; PORTINARO, Píer Paolo; LUTHER, Jörg (Orgs.). II Futuro della Constituzione. Torino: Einaudi, 1996, p. 8.

${ }_{49}$ Ressalte-se que para Luhmann "Os acoplamentos estruturais são aquisições evolutivas". Idem, p. 29.

${ }_{50}$ CORSI, Giancarlo. "Sociologia da Constituição". Revista da Faculdade de Direito da Universidade Federal de Minas Gerais. Trad. Juliana Neuenschwander Magalhães. № 39. Belo Horizonte: jan./jun. 2001, p. 3.

${ }^{51}$ LUHMANN, Niklas. "A Constituição como Aquisição Evolutiva". Trad. de Menelick de Carvalho Netto (para fins acadêmicos). In: ZAGREBELSKY, Gustavo; PORTINARO, Píer Paolo; LUTHER, Jörg (Orgs.). II Futuro della Constituzione. Torino: Einaudi, 1996, p. 4.

${ }^{52}$ Sobre os paradoxos na teoria de Luhmann, Cf. GUIMARÃES, Guilherme F. A. Cintra. O uso criativo dos paradoxos do direito na aplicação de princípios constitucionais: abertura, autoritarismo e pragmatismo na jurisdição constitucional brasileira. Dissertação de Mestrado. Faculdade de Direito da Universidade de Brasília, 2007.

53 "Em suma, portanto, o código direito/não-direito gera a Constituição para que a Constituição possa gerar o código direito/não-direito." Idem, p. 12. 
a legitimação da constituição como texto jurídico ao ato político da assembléia "constituinte" e à legislação. Em com essa operação, horizontes de possibilidades antes impensáveis são abertos, o que torna a Constituição "um fator de liberdade",54.

Passada a premissa de que o direito se autofunda ${ }^{55}$, parece importante adentrar no seu conteúdo constitucional. E aqui se faz um diálogo com aquilo que já foi dito até aqui sobre os direitos fundamentais - em especial sobre o princípio da igualdade - que não indicam no caso concreto o seu sentido. Como diria Corsi "não indica situações ou comportamentos imediatamente imagináveis como fatispécies, mas de que se propõe como um pano de fundo normativo sobre o qual se pode projetar aquilo que, mais concretamente, depois será considerado como sendo normatividade ordinária." ${ }^{56}$ Mas, então como pode o direito servir para a resolução de casos, por meio de decisões?

Para responder à pergunta, o autor faz a distinção entre sistema social do direito (subsistema da sociedade moderna) e organizações formais ${ }^{57}$ (no interior daquele). Como esclarece, a diferenciação entre esses dois elementos é muito importante por dois motivos, essenciais à compreensão dos direitos fundamentais.

O primeiro deles é a programação operacional do direito. Isso porque o direito não opera com um programa finalístico, pois trabalha com o tipo condicional (a forma "se/então"). Isso faz com que seja "necessário poder confiar a decisão às organizações formais" ${ }^{58}$, pois só assim se pode alcançar a decisão.

O segundo motivo - não menos importante - é o de que os valores e princípios sejam traduzidos em programas de decisão ${ }^{59}$. Isso porque, como já ressaltamos antes neste trabalho, os princípios fundamentais (classicamente pensados como liberdade e igualdade) foram formulados de modo a não terem nenhuma consistência semântica: são vazios de conteúdo ${ }^{60}$. Logo, podem ser vistos das mais diversas formas. Mas, isso não é uma crítica aos direitos fundamentais e sim um meio de viabilizar a sua função. E o papel das estruturas é essencial para essas diferenças sejam produzidas e possam ser também compensadas. Então, os valores só tem sentido se especificados

\footnotetext{
54 CORSI, Giancarlo. "Sociologia da Constituição". Revista da Faculdade de Direito da Universidade Federal de Minas Gerais. Trad. Juliana Neuenschwander Magalhães. No 39. Belo Horizonte: jan./jun. 2001, pp. 3-4.

${ }^{55}$ Como afirma Corsi: "a constituição serve para regular os procedimentos de produção do direito e, mediante esta, o direito regula a sua própria dinâmica (...)." Op. Cit. p. 4.

${ }^{56}$ Op. Cit. p.4.

57 Seria um tipo de sistema social que produz decisões. Aqui, o papel central seria o dos Tribunais, mas, lembre-se que o direito não se exaure nas suas organizações formais, havendo outras formas de reprodução. Op. Cit. p. 5.

${ }^{58}$ Op. Cit. p.6.

${ }^{59}$ Op. Cit. p.6.

${ }^{60}$ Op. Cit. p.6.
}

DiREITOS FundAMENTAIS E JUSTIÇA - ANO 6, N' 18, P. 178-202, JAN./MAR. 2012 
em um contexto organizado, ou seja, no interior de procedimentos. ${ }^{61}$ Usando o exemplo da igualdade, explica:

O princípio da igualdade, para tomarmos o exemplo mais evidente, é universalmente aceito apenas porque, de fato, não especifica os critérios de sua aplicação; dizendo de outro modo, porque não oferece nenhum elemento para o seu reconhecimento. O reconhecimento da igualdade é deixado para o aparato organizacional e apenas através do procedimento podem ser construídos argumentos para que se decida se as diferenças encontradas são compatíveis com o princípio da igualdade. Dessa forma origina-se a incerteza sobre a decisão final que caracteriza e justifica as modernas burocracias. ${ }^{62}$

Então, a certeza do direito não é quanto à justiça, mas sim quanto à decisão. $E$ nesse processo, os direitos fundamentais tem o sentido de abrir um espaço de contingência completamente indeterminado, em que os aparatos organizacionais e os seus procedimentos internos podem especificar determinadas formas. Isso faz necessário perceber como "o direito constrói a sua própria capacidade de operar sobre uma base temporal, garantindo que dentro das organizações, objetivos, condições, futuro e passado se combinem. $^{63}$

E no papel de abertura, para um horizonte de possibilidades reaparecem como ponto central os direitos fundamentais, afinal, não representam decisório imediato ${ }^{64}$ e detém a função de abrir espaço para uma enorme quantidade de vínculos e diferenças. Então, o papel dos direitos fundamentais deve ser buscado na relação que a sociedade instala com seus próprios horizontes, ou seja, com o passado e com o futuro. Percebe-se na história dos direitos fundamentais uma progressiva perda das referências reais ${ }^{65}$,

${ }^{61}$ Op. Cit. p.7.

${ }^{62}$ Op. Cit. p. 7.

63 CORSI, Giancarlo. "Sociologia da Constituição". Revista da Faculdade de Direito da Universidade Federal de Minas Gerais. Trad. Juliana Neuenschwander Magalhães. № 39. Belo Horizonte: jan./jun. 2001, p. 8.

${ }^{64}$ Sobre essa colocação, Corsi pondera que "Sem dúvida elas são também isso, mas é evidente que a realidade social impõe condições que são de tal forma distantes do ideal, que os valores compartilhados acabam sendo exatamente aqueles que não encontram uma adequada correspondência nos fatos." Op. Cit. p. 8.

${ }^{65}$ Como seria o melhor exemplo o próprio racismo, superado na história americana. Paulo Blair utiliza o exemplo americano para desmistificar a duração de mais de 200 anos da constituição americana. Explica: "Mesmo a Constituição dos EUA, saudada como modelo de concisão e que por isso teria durado mais de duzentos anos, não poderia durar por tanto tempo se não fosse compreendida como objeto dessa interminável reconstrução interpretativa. É por este motivo que, no passado, compreendia-se que a Constituição norte-americana não permitia à legislação federal impor garantias contratuais trabalhistas como um salário-mínimo vigente em toda a União, e, em outro momento histórico posterior, a interpretação dada ao texto constitucional sem mudança em sua redação - levou a uma compreensão oposta. A vitalidade da Constituição norte-americana reside não em seu texto ou 'tamanho', mas na absoluta compreensão de que o seu sentido é sempre o resultado de uma interpretação". Cf. OLIVEIRA, Paulo Henrique Blair de. Discutindo o essencial. In: Observatório da Constituição e da Democracia, Brasília, no 1, 2006, p. 10. 
que culmina com o direito moderno neutralizando o passado, expondo-se assim a um futuro imprevisível e ignorado ${ }^{66}$.

A complexidade dessa construção é a seguinte: "No presente decide-se sobre uma constituição que deverá valer no futuro como um passado vinculante, mas apenas até que em um presente futuro não se decida modificá-la. ${ }^{, 67} \mathrm{E}$ nesse processo, os direitos fundamentais constitucionalizados aparecem como "símbolos de futuras diferenças, são unidades que têm sentido apenas como diferenças ainda desconhecidas e sobre as quais se deverá (eventualmente) decidir.

E aqui nos parece que está a função do princípio da igualdade para decidir sobre a constitucionalidade, ou não, da política de cotas raciais como instrumento de acesso às universidades. $E$ isso é aceito, sem negar ao direito seu caráter fluído, para se manter ao direito "margens de liberdade historicamente sem precedentes". Os direitos fundamentais dão à constituição condições de "construir e desconstruir continuamente suas próprias formas"68. Eles inauguram o desafio de pensar, e repensar um futuro que nos é incerto, transferindo para nós a responsabilidade de pensar esse futuro incerto.

\section{UMA POSSÍVEL INTERPRETAÇÃO SOBRE COTAS RACIAIS}

Como já referido, em 20.7.2009, o Partido Democratas (DEM) propôs a Arguição de Descumprimento de Preceito Fundamental (ADPF) $n^{\circ} 186$ no intuito de declarar inconstitucional a política de cotas da UnB (Resolução $n^{\circ}$ $38 / 2003 /$ CEPE/UNB) que reserva $20 \%$ das vagas universitárias, durante 0 período de 10 anos, para aqueles que se afirmem negros em todos os cursos da universidade ${ }^{69}$. Em 31.07.2009 o Ministro Gilmar Mendes, na qualidade de presidente do STF e ante a sua competência durante o recesso judicial, indeferiu o pedido liminar ${ }^{70}$ por não existir a urgência, já que os vestibulares ocorrem no início do ano, mas destacou a necessidade de melhor apreciação dessa matéria ${ }^{71}$. Algum tempo depois, foram realizadas

${ }^{66}$ CORSI, Giancarlo. "Sociologia da Constituição". Revista da Faculdade de Direito da Universidade Federal de Minas Gerais. Trad. Juliana Neuenschwander Magalhães. № 39. Belo Horizonte: jan./jun. 2001, p. 8.

${ }^{67}$ Idem, p.10.

68 CORSI, Giancarlo. "Sociologia da Constituição". Revista da Faculdade de Direito da Universidade Federal de Minas Gerais. Trad. Juliana Neuenschwander Magalhães. № 39. Belo Horizonte: jan./jun. 2001, p. 11.

${ }^{69}$ Petição Inicial dos Democratas. Disponível em: http://redir.stf.jus.br/estfvisualizadorpub/jsp/ consultarprocessoeletronico/ConsultarProcessoEletronico.jsf?seqobjetoincidente=2691269. Acesso em 06.09.2010.

${ }^{70}$ Decisão monocrática na ADPF $n^{\circ}$ 186. Disponível em: http://www.stf.jus.br/Portal/processo/ verProcessoAndamento.asp?incidente=2691269. Acesso em 16.08.2011.

${ }^{71}$ No intuito de demonstrar a sua descrença no modelo de autodeclaração e avaliação da raça pelo seu fenótipo, o Ministro Gilmar Mendes narrou em sua decisão o seguinte caso: "Em 2004, o irmão da candidata Fernanda Souza de Oliveira, filho do mesmo pai e da mesma mãe, foi considerado "negro", mas ela não. Em 2007, os gêmeos idênticos Alex e Alan Teixeira da Cunha foram considerados de "cores diferentes" pela comissão da UnB. Em 2008, Joel Carvalho de Aguiar foi considerado "branco" pela Comissão, enquanto sua filha Luá Resende Aguiar foi 
audiências públicas ${ }^{72}$ pelo Supremo Tribunal Federal no intuito de garantir a participação social nos debates, mas ainda não se definiu data para o julgamento da ação.

O principal argumento defendido pelo partido político na ADPF 186 é o de que o critério raça é inválido para ações afirmativas.

Desenvolvendo essa premissa, o Partido Democratas afirmou que ninguém é excluído socialmente por ser negro, mas sim por ser pobre ${ }^{73}$. Segundo o DEM, a UnB instituiu o racismo ao criar um "Tribunal Racial" "4 para definir quem é negro no Brasil. Nos termos da petição inicial, com tal ato, a UnB teria "ressuscitado idéias nazistas" 75 ao definir cotas raciais. Para o partido político, a única forma legítima para a definição das cotas raciais seria por meio da análise genômica dos ancestrais de cada candidato. Em outras palavras, o DEM só aceita a análise de DNA de cada vestibulando como critério para ações afirmativas pautadas na raça.

Apesar de tais argumentos, o DEM arrolou como premissas o reconhecimento da existência do racismo e a importância das ações afirmativas. Contraditoriamente, o primeiro de seus fundamentos é exatamente a não negação quanto à existência do racismo. Na própria inicial, dentre os esclarecimentos prévio, o DEM afirmou desde logo que "Não se discute, nesta ação, sobre a existência do Racismo, de Preconceito e de Discriminação na sociedade brasileira, nem que tais medidas representam chagas que devem ser banidas, combatidas e punidas, com o máximo de rigor na órbita individual e na esfera coletiva." ${ }^{\text {"7 }}$ Mas, em seguida, o partido afirmou que é impossível a definição pelo critério raça, de cotas de acesso às universidades.

considerada "negra", mesmo, segundo Joel, a mãe de Luá sendo "branca". A adoção do critério de análise do fenótipo para a confirmação da veracidade da informação prestada pelo vestibulando pode suscitar alguns problemas". Cf. Decisão Monocrática na ADPF $n^{\circ} 186$. Disponível em: http://www.stf.jus.br/portal/processo/verProcessoAndamento.asp?incidente=2691269. Acesso em 16.08.2011. Apesar de reconhecer a possibilidade de equívocos na aplicação da política de cotas raciais, à luz das premissas desse artigo a política pública permanece sendo urgente e de natureza a concretizar a constituição.

${ }^{72}$ Houve audiência pública realizada pelo Supremo Tribunal Federal, no bojo da ADPF no 186 e do RE $n^{\circ} 597.285 / R S$, da relatoria do ministro Ricardo Lewandowski sobre políticas de ação afirmativa para reserva de vagas no ensino superior. Durante 3 (três) dias, 38 (trinta e oito) especialistas de diversas entidades da sociedade civil e representantes dos Três Poderes debateram a utilização de critérios raciais para a reserva de vagas nas universidades públicas. Foram ouvidos, por exemplo: ANDIFES, UNE, UNICAMP, AJUFE, FUNAI, MEC e o Deputado Demóstenes Torres. Cf. Disponível em: http://www.stf.jus.br/portal/processo/verProcesso Andamento.asp?incidente=2691269. Acesso em 16.08.2011.

${ }^{73}$ Petição Inicial dos Democratas. Disponível em: http://redir.stf.jus.br/estfvisualizadorpub/jsp/ consultarprocessoeletronico/ConsultarProcessoEletronico.jsf?seqobjetoincidente=2691269. Acesso em 20.09.2010.

${ }^{74}$ Op.Cit.

${ }^{75}$ Op.Cit.

${ }^{76}$ Op. Cit. 
Ao se olhar com mais atenção a questão, torna-se possível notar os equívocos de cada um desses argumentos, dentro da perspectiva do princípio da igualdade inserido na constituição de $1988^{77}$.

O principal dos fundamentos adotados pelo DEM seria o de que para a biologia não existem raças. Mas, aqui há um erro de premissa que precisa ser notado. A discussão não se pauta em um problema científico, mas sim em um problema social. A questão em exame é sobre as práticas discriminatórias pautadas na cor e não em conceitos de biologia. A diferença está no tratamento diferente dispensado às pessoas em decorrência da cor de sua pele e não na noção de ancestralidade ${ }^{78}$. "Quando nos referimos à raça, devemos entender o seu sentido como sendo social, e não biológico" "79. Eis aqui um claro ponto que remete à importância das particularidades históricas e culturais, para as quais Waldron chamou atenção em seu trabalho sobre os direitos fundamentais. A constituição - ao incluir dentre os seus direitos a igualdade - abre espaço para a discussão, mas a sua concretização necessariamente passa pela análise das particularidades sociais e culturais do Brasil. Como explicado por Edgar Morin:

[...] é impossível conceber a unidade complexa do humano por intermédio do pensamento disjuntivo, que concebe a nossa humanidade de maneira insular por fora do cosmo que o rodeia, da matéria física e do espírito do qual estamos constituídos, nem tão pouco por intermédio do pensamento redutor que reduz a unidade humana a um substracto puramente bio-anatómico. $^{80}$

A observação, e aplicação, do princípio da igualdade precisa se adequar necessariamente pelas características sociais e culturais dos brasileiros.

Aceita essa premissa, conseguimos verificar com mais clareza o equívoco de se achar que o problema racial se resume à questão econômica ${ }^{81}$. Ora, os fundamentos aqui são autônomos. Não se pode dizer que só existe preconceito de cor se a pessoa for pobre. Por outro lado, não se pretende negar que existe o preconceito de classe. O preconceito em razão da cor da pele não está atrelado à condição social, e ambas - cor da pele e condição

\footnotetext{
77 Ver: PAIXÃO, Cristiano; CARVALHO NETTO, Menelick. Entre Permanência e Mudança: reflexões sobre o conceito de constituição. Carlos Alberto Molinaro; Mariângela Guerreiro Milhoranza; Sérgio Gilberto Porto (Org.). In: Constituição, Jurisdição e Processo - Estudos em Homenagem aos 55 anos da Revista Jurídica. 1. ed., Sapucaia do Sul, RS: Notadez, 2007.

${ }^{78}$ AZEVEDO, Damião Alves de. Trazendo o Racismo a Luz. In Artigos da UNB. Brasília. 2009. Agosto. Disponível em: http://www.unb.br/noticias/unbagencia/artigo.php?id=182. Acesso em: 07.08.2010.

${ }^{79}$ PISCITELLI, Rui Magalhães. O Estado como Promotor de Ações Afirmativas e a Política de Cotas para o Acesso dos Negros à Universidade. Curitiba: Juruá, 2009.

${ }^{80}$ MORIN, Edgar. Os Sete Saberes para a Educação do Futuro. Ana Paula Viveiros (Trad.). Lisboa: Instituto Piaget, 2002, p. 52.

${ }^{81}$ Petição Inicial dos Democratas. Disponível em: http://redir.stf.jus.br/estfvisualizadorpub/jsp/ consultarprocessoeletronico/ConsultarProcessoEletronico.jsf?seqobjetoincidente=2691269. Acesso em 06.09.2010.
}

DiREITOS FUNDAMENTAIS E JUSTIÇA - ANO 6, N' 18, P. 178-202, JAN./MAR. 2012 
social - são fatores independentes, e às vezes interligados, de segregação social. ${ }^{82}$ Por isso, a constatação do fator condição social não anula a segregação histórica promovida pela questão da pele. E a constituição, nos seus direitos fundamentais, confere a abertura para discussões como esta das cotas sociais.

Note-se que existem alguns dados que demonstram a distinção de cor, até mesmo dentro dos cargos públicos. O elemento que se pretende discutir aqui é o fenótipo. A título de exemplo, de 620 procuradores da república, só 7 são negros (98, 6\% são brancos); na câmara dos deputados, de 513, apenas 20 são negros (4\% são negros); no senado, de 81 , só 2 são negros (97 \% são brancos). ${ }^{83}$

Nas palavras da petição inicial e, na de muitos estudiosos, a pretensa solução para o problema do preconceito racial seria a miscigenação do Brasil, ou seja, a sua mistura de raça. Afirma-se: no Brasil, há mistura das raças, logo, uma política afirmativa pautada na cor, por via transversa, seria racista. Por meio da política pública, o DEM defende que se estaria criando um racismo que pretensamente não existe. Haveria, então, uma polarização da sociedade.

Segundo a petição inicial a análise da ação afirmativa dependeria de seu contexto histórico, econômico, social e cultural em que foram implementadas. $^{84} \mathrm{E}$ que no Brasil, temos um contexto não-racista, diante de nossa miscigenação. Ocorre que, se nos voltarmos para o nosso contexto, podemos desconstruir facilmente esses argumentos. Uma pesquisa recente do IPEA, por exemplo, concluiu que $45,3 \%$ da população é formada por negros, sendo que estes representam 64\% dos pobres e 69\% dos indigentes $^{85}$. Não bastasse isso, o mesmo estudo explica que do total de estudantes no ensino superior, apenas 2\% são negros. Então, não parece certo afirmar que os negros detém o mesmo tratamento dos brancos.

Não bastassem esses dados empíricos, o equívoco de tal raciocínio está em se esquecer de dois pontos: a) se existe miscigenação, é porque existem raças antes definidas e b) somos indivíduos diferentes, que se identificam.

Ora, o objetivo da política pública é afirmar a raça ${ }^{86}$. Não por outra razão o nome de tal política pública é ação afirmativa. As raças existem e

\footnotetext{
82 AZEVEDO, Damião Alves de. A Justiça e as Cores: a possibilidade de adequação constitucional de ações afirmativas voltadas para negros e indígenas no ensino superior. Dissertação de Mestrado. Faculdade de Direito da Universidade de Brasília, 2007.

${ }^{83}$ CARVALHO, José Jorge de. Inclusão Étnica e Racial no Brasil: a questão das cotas no ensino superior. São Paulo: Attar, 2005, p. 33.

${ }^{84}$ Petição Inicial dos Democratas. Disponível em: http://redir.stf.jus.br/estfvisualizadorpub/jsp/ consultarprocessoeletronico/ConsultarProcessoEletronico.jsf?seqobjetoincidente=2691269. Acesso em 06.09.2010.

${ }^{85}$ LOPES, Nei. O Racismo Explicado aos meus Filhos. Rio de Janeiro: Agir, 2007, p. 169.

${ }^{86}$ Sobre a importância do ato de afirmar, sugere-se a leitura do capítulo 2 deste trabalho.
} 
não dá para negar este fato. O erro no raciocínio é entender que vivemos em uma nação monocromática.

Não se pode negar que, pela aparência, alguém pode ser - e é identificado como pertencente a um grupo desprezado socialmente. A questão do racismo não se pauta na questão genética, mas sim na aparência. A distinção está no olhar, na pele, e não em sua definição biológica ${ }^{87}$.

Pensar de maneira diversa torna aquele que se sente discriminado em alguém equivocado (afinal, não existiriam raças, logo, não há porque ele se sentir assim) e ainda por cima racista (ele é quem está pretensamente criando o racismo). Em outras palavras, a vítima do preconceito converte-se em vilão.

Fechar os olhos para isso é fingir que não existe diferença entre o tratamento de um negro e um branco em uma entrevista de trabalho, por exemplo. O Brasil não viveu uma história de conflitos coletivos motivados pela cor, como aquela vivida pelos EUA, mas, isso não impede o surgimento e a permanência do racismo na história brasileira ${ }^{88}$. Prova disso é o fato de que políticas raciais têm sido reivindicadas ao menos desde 1915, quando cidadãos negros criaram, em São Paulo, o primeiro jornal em prol da inclusão negra. ${ }^{89}$

As políticas afirmativas pretendem exatamente alterar este contexto social para deixar de existir no futuro. E a discussão sobre o conceito fluido da igualdade (o que já se percebeu na criação da ideia de constituição surgida na França e nos Estados Unidos) garante a abertura para um debate atual e futuro sobre a densificação desses direitos.

É preciso reconhecer que o debate sobre a igualdade racial precisa e está sendo feito no julgamento e no debate social inaugurado pela ADPF $\mathrm{n}^{\circ} 186$ - para conferir densidade aos direitos fundamentais. Isso se torna especialmente urgente quanto às cotas, afinal, o objetivo de uma ação afirmativa é exatamente desaparecer, pois espera-se que tais medidas compensatórias não sejam mais necessárias no futuro ${ }^{90}$. Não se espera pôr fim ao preconceito, mas sim, evitar que a sua expressão ocorra de maneira

\footnotetext{
87 AZEVEDO, Damião Alves de. A Justiça e as Cores: a possibilidade de adequação constitucional de ações afirmativas voltadas para negros e indígenas no ensino superior. Dissertação de Mestrado. Faculdade de Direito da Universidade de Brasília, 2007.

${ }^{88}$ A demanda por políticas educacionais e pela admissão de negros na universidade consta em documentos elaborados por movimentos negros brasileiros nos anos 30 e 40, anteriores, à existência de ações afirmativas nos EUA. Cf. AZEVEDO, Damião Alves de. Trazendo o racismo a luz. In Artigos da UNB, Brasília, 2009, Agosto, Disponível em: http://www.unb.br/ noticias/unbagencia/artigo.php?id=182. Acesso em: 07.08.2010.

${ }^{89}$ AZEVEDO, Damião Alves de. Trazendo o racismo a luz. In Artigos da UNB. Brasília. 2009. Agosto. Disponível em: http://www.unb.br/noticias/unbagencia/artigo.php?id=182. Acesso em: 07.08.2010.

90 AZEVEDO, Damião Alves de. A Justiça e as Cores: a possibilidade de adequação constitucional de ações afirmativas voltadas para negros e indígenas no ensino superior. Dissertação de Mestrado. Faculdade de Direito da Universidade de Brasília, 2007.
} 
crônica e sistemática como mecanismo de exclusão e discriminação. Como reação à manutenção de um cenário excludente, a política de cotas pretende incluir o desigual, por meio do acesso à universidade. Em outras palavras, o que se espera das cotas raciais é considerar todos os membros da comunidade como iguais, não permitindo a sua exclusão ${ }^{91}$ social.

E aqui é que entra o papel do princípio da igualdade. Na construção de um papel inclusivo na sociedade, que pode sempre ser problematizado e repensado. ${ }^{92} \mathrm{Em}$ uma conceituação da igualdade que tem se moldado, "através dos tempos, às novas necessidades sociais". Ocorre aqui uma "agregação de significados no decorrer da história, fazendo do princípio da igualdade o preceito complexo que ora se apresenta ${ }^{93}$. Essa empreitada permanece sendo um processo, sempre aberto e em construção. O direito constitucional necessariamente precisa lidar com essas permutas, com esses jogos de força $a^{94}$ insertos no significado do princípio da igualdade, pois Ihe são constitutivas ${ }^{95}$.

Os artigos $3^{\circ}$, IV, e $4^{\circ}$, VIII, e $5^{\circ}$, LXII, da Constituição Federal, respectivamente, vedam o preconceito e a discriminação; repudiam 0 racismo e pregam o combate ao racismo. Mas, dar sentido a tais diretrizes é tarefa nossa, a ser construída em nossa vivência. O que se almeja, então, é "lidar produtivamente com o problema da indeterminação estrutural do direito" ${ }^{\prime 96}$. Ora, como já se disse, esse é o papel dos direitos fundamentais. Os discursos constitucionais produzidos sobre o texto é que podem inventar

\footnotetext{
${ }^{91}$ No caso da UFBA, Naomar de Almeida Filho esclarece que apesar de uma boa proporção de aluno que ingressam na universidade se autodeclararem negros ou pardos, há vários cursos em que essa proporção é menor do que $30 \%$, como seria o caso dos cursos de Direito, Odontologia, Arquitetura, Engenharia elétrica, Engenharia civil e Medicina. Isso demonstra que no caso de tais cursos, a exclusão ocorre antes mesmo da submissão ao vestibular. Cf. ALMEIDA FILHO, Naomar de. Ações Afirmativas na UFBA. In: Universidade Nova: Textos críticos e esperançosos. Brasília: Editora Universidade de Brasília, Salvador: EDUFBA, 2007, p. 95.

${ }_{2}$ CARVALHO NETTO, Menelick de. A Hermenêutica Constitucional e os Desafios postos aos Direitos Constitucionais. SAMPAIO, José Adécio Leite (Org.). In Jurisdição Constitucional e Direitos Fundamentais. Belo Horizonte: Del Rey. 2003.

93 BELLINTANI, Leila Pinheiro. "AÇÃO AFIRMATIVA" E OS PRINCÍPIOS DO DIREITO: A questão das Quotas Raciais para o Ingresso no Ensino Superior no Brasil. Rio de Janeiro: Lumen Juris, 2006, p. 20.

${ }^{94}$ BENVINDO, Juliano Zaiden. Que Diferença Inclui o Diferente? A Diferença e a Reconstrução Reflexiva da Alteridade. Novos Estudos Jurídicos (UNIVALI), v. 15, 2010. Para uma análise com a articulação entre equivalência e diferença, para a construção de uma identidade política com a demarcação das fronteiras entre o NÓS e o ELES, ver: MAYORGA, Claudia; COSTA, e PRADO, Marco Aurélio Máximo. Democracia, Instituições e a Articulação de Categorias Sociais. In: Universidade Cindida, Universidade em Conexão: Ensaios sobre a democratização da universidade. Belo Horizonte: Editora UFMG, 2010.

${ }_{95}$ CARVALHO NETTO, Menelick de; SCOTTI, Guilherme. Os Direitos Fundamentais e a (In)Certeza do Direito: A produtividade das tensões principiológicas e a superação do sistema de regras. Belo Horizonte: Fórum, 2011.

${ }^{96}$ Op. Cit. p. 13.
} 
e reinventar a identidade constitucional ${ }^{97}$. É por meio deles que podemos construir um futuro ainda em aberto para os direitos fundamentais, dentre os quais se insere a igualdade.

Não bastam as cotas raciais. É preciso pensá-las apenas como um dos fatores que podem reconstruir uma história que valorizes os afrodescendentes. É sempre, então, urgente preparar as escolas, as outras instituições, o mercado de trabalho, a saúde, dentre outros campos para os novos tempos ${ }^{98}$. E a percepção de que é imperativo repensar tudo isso passa necessariamente pela clareza do desafio do direito constitucional à igualdade. Não adianta pretender fechar o conceito da igualdade como se não houvesse uma amanhã por vir ${ }^{99}$. Enfrentemos os desafios que se apresentarão neste caminho.

\section{CONCLUSÃO}

O princípio da igualdade, quanto à sua aplicação, pode empreender diversos usos. Como se buscou apresentar neste trabalho a igualdade pode ser o fundamento para garantir o acesso de alunos negros, por meio de cotas, nas universidades brasileiras. Em contrapartida, pode também significar argumento hábil a imputar a tais políticas públicas a pecha da inconstitucionalidade. Então, como devemos pensar o princípio da igualdade?

Em busca de uma resposta para essa pergunta, este estudo visou reconstruir a importância - aprendida no constitucionalismo francês e americano - da formulação de um texto constitucional, com a necessária inserção de direitos fundamentais com conceitos maleáveis nas constituições. As possibilidades futuras de revisão daquilo que permanece no texto, diante da interpretação, pôde ser vislumbrada na França e nos Estado Unidos, e permanece válida - e por consequência segue sendo reconstruída - nos dias de hoje. O ponto central a ser compreendido com os constitucionalismos francês e americano é a importância quanto aos direitos fundamentais (dentre os quais se encontra a igualdade) de declará-los e de se manter o seu conteúdo aberto.

Apesar de saber da fluidez de conceitos como a igualdade, isso de maneira alguma pode significar que se trata de um princípio sem qualquer sentido prático. A tarefa aqui empreendida era demonstrar exatamente o oposto de tal raciocínio. Defendemos a igualdade como um princípio essencial, com todos os seus problemas e riscos, para a construção de

\footnotetext{
97 ROSENFELD, Michel. A Identidade do Sujeito Constitucional. Menelick de Carvalho Netto (Trad.). Belo Horizonte: Mandamentos, 2003, p. 39-40.

${ }^{8}$ Interessante que em seu livro sobre racismo, Lei Lopes afirma que só a UGF - Universidade Federal de Goiás tem mais de $1 \%$ de professores negros. Na UFG há 1,2\%. Para que se tenha noção do desafio, explica que a UFRJ, que foi a primeira a instituir as cotas tem $0,21 \%$ de negros, dentre os seus 2.300 professores. Cf. LOPES, Nei. O Racismo explicado aos meus Filhos. Rio de Janeiro: Agir, 2007, p. 170.

${ }_{99}$ DERRIDA, Jacques. Força de Lei: o fundamento místico da autoridade. Leyla Perrone-Moisés (Trad.). São Paulo: Martins Fontes, 2007.
} 
uma sociedade democrática. Como explicam Corsi e Luhmann, podemos aprender com a abertura que a constituição - e seus direitos fundamentais podem nos conceder para a construção de um futuro em aberto. Uma constante revisão e afirmação das premissas de nossa vida em sociedade. Esse futuro nos pertence. E nesse trajeto, a constituição pode ser esse instrumento de acoplamento entre a política e o direito que pode nos permitir lidar com essa complexidade.

Se aplicado esse raciocínio à análise de constitucionalidade da política de cotas raciais nas universidades, continuaremos sem ter uma resposta fácil, sem riscos. Mas, ao mesmo tempo é certo que poderemos dar início ao debate para tentar construir essa resposta, dentro de nosso contexto, aprendendo com nossos erros e acertos. Não existem soluções mágicas para o direito constitucional e seus direitos fundamentais. Precisamos tratar a questão de maneira madura, com bastante debate e reflexão, o que parece ser viável com a ampla discussão inaugurada com a ADPF 186, a ser julgada pelo Supremo Tribunal Federal.

Não pretendemos negar que as cotas raciais talvez possam causar algumas injustiças, como exemplificado na decisão do Ministro Gilmar Mendes. No entanto, o que nos parece certo é que podemos aprender muito com essa política e buscar rever um quadro de desigualdade que contém sintomas crônicos.

Cruz e Souza, o chamado poeta negro que escreveu a poesia que abre este trabalho, nasceu em 1861, escravo. Aos quatro anos de idade, foi liberto. Formou-se professor e produziu literatura. Em 1894, foi nomeado promotor em Laguna, Santa Catarina, mas a cor o impediu de assumir o cargo. A despeito de seu preparo, e do reconhecimento de sua poesia, não obteve bons empregos. A questão não estava na célula, ou na existência de raças. O problema já era - e continua sendo - social e está estampado na discriminação decorrente da cor da pele. Esse exemplo pode servir para a reflexão de que continuamos vivendo em uma sociedade excludente, em razão do fenótipo, há séculos e pouco - ou nada - de tal estrutura se alterou. Então, propomos: que tal refletir sobre a proposta e encarar o desafio dos problemas raciais com seriedade? O futuro continua aberto, mas quem escreve essa história somos nós.

\section{REFERÊNCIAS}

ALMEIDA FILHO, Naomar de. Ações Afirmativas na UFBA. In: Universidade Nova: Textos Críticos e Esperançosos. Brasília: Editora Universidade de Brasília, Salvador: EDUFBA, 2007, p. 95.

AZEVEDO, Damião Alves de. A Justiça e as Cores: a possibilidade de adequação constitucional de ações afirmativas voltadas para negros e indígenas no ensino superior. Dissertação de Mestrado. Faculdade de Direito da Universidade de Brasília, 2007.

Trazendo o Racismo a Luz. In Artigos da UNB. Brasília, 2009, Agosto, Disponível em: http://www.unb.br/noticias/unbagencia/artigo.php?id=182. Acesso em: 07.08.2010. 
BELLINTANI, Leila Pinheiro. "AÇÃO AFIRMATIVA" E OS PRINCÍPIOS DO DIREITO: A questão das Quotas Raciais para o Ingresso no Ensino Superior no Brasil. Rio de Janeiro: Lumen Juris, 2006.

BENVINDO, Juliano Zaiden. Que Diferença Inclui o Diferente? A Diferença e a Reconstrução Reflexiva da Alteridade. Novos Estudos Jurídicos (UNIVALI), v. 15, 2010.

BULOS, Uadi Lammêgos. Curso de Direito Constitucional. São Paulo: Saraiva, 2009.

CARVALHO, José Jorge de. Inclusão Étnica e Racial no Brasil: a questão das cotas no ensino superior. São Paulo: Attar, 2005.

CARVALHO NETTO, Menelick de. A Hermenêutica Constitucional e os Desafios postos aos Direitos Constitucionais. SAMPAIO, José Adécio Leite (Org.). In Jurisdição Constitucional e Direitos Fundamentais. Belo Horizonte: Del Rey. 2003.

As Lições da Revisão. In: Observatório da Constituição e da Democracia, Brasília, $n^{\circ}$ 1, 2006.

CARVALHO NETTO, Menelick de; SCOTTI, Guilherme. Os Direitos Fundamentais e a (In)Certeza do Direito: A produtividade das tensões principiológicas e a superação do sistema de regras. Belo Horizonte: Fórum, 2011.

CORSI, Giancarlo. "Sociologia da Constituição". Revista da Faculdade de Direito da Universidade Federal de Minas Gerais. Trad. Juliana Neuenschwander Magalhães. $N^{0}$ 39. Belo Horizonte: jan./jun. 2001.

Decisão Monocrática na ADPF $n^{\circ} 186$. Disponível em:

http://www.stf.jus.br/portal/processo/verProcessoAndamento.asp?incidente=2691269. Acesso em 16.08.2011.

DERRIDA, Jacques. Declarations of Independence. In: Negotiations: interventions and interviews (1971-2001). Stanford: Stanford University Press, 2002.

. Força de Lei: o fundamento místico da autoridade. Leyla Perrone-Moisés

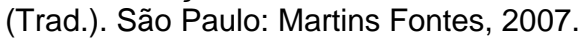

DIPPEL, Horst. Os Direitos Humanos na América, 1776-1849: redescobrindo o contributo dos Estados. In: . História do Constitucionalismo Moderno - Novas Perspectivas. Trad. António Manuel Hespanha e Cristina Nogueira da Silva. Lisboa: Calouste Gulbenkian, 2007.

GUIMARÃES, Guilherme F. A. Cintra. O Uso Criativo dos Paradoxos do Direito na Aplicação de Princípios Constitucionais: Abertura, Autoritarismo e Pragmatismo na Jurisdição Constitucional Brasileira. Dissertação de Mestrado. Faculdade de Direito da Universidade de Brasília, 2007.

HUNT, Lynn. "Eles deram um grande exemplo": declarando os direitos. In: A Invenção dos Direitos Humanos - Uma História. Trad. Rosaura Eichenberg. São Paulo: Companhia das Letras, 2009.

LINHARES, Mônica Mansur. Autonomia Universitária no Direito Educacional Brasileiro. São Paulo: Segmento, 2005.

LOPES, Nei. O Racismo explicado aos meus Filhos. Rio de Janeiro: Agir, 2007.

LUHMANN, Niklas. "A Constituição como Aquisição Evolutiva". Trad. de Menelick de Carvalho Netto (para fins acadêmicos). In: ZAGREBELSKY, Gustavo; PORTINARO, Píer Paolo; LUTHER, Jörg (Orgs.). Il Futuro della Constituzione. Torino: Einaudi, 1996. 
LUHMANN, Niklas. Sociologia do Direito 1. Trad. Gustavo Bayer. Rio de Janeiro: Edições Tempo brasileiro, 1983.

MADISON, James. Federalista $n^{\circ} 10$ e $n^{0} 51$. In: HAMILTON, Alexander; JAY, Jonh. O Federalista. Trad. Heitor Almeida Herrera. Brasília: Universidade de Brasília, 1984.

MAYORGA, Claudia; COSTA e PRADO, Marco Aurélio Máximo. Democracia, Instituições e a Articulação de Categorias Sociais. In: Universidade Cindida, Universidade em Conexão: Ensaios sobre a Democratização da Universidade. Belo Horizonte: Editora UFMG, 2010.

MORIN, Edgar. Os Sete Saberes para a Educação do Futuro. Ana Paula Viveiros (Trad.). Lisboa: Instituto Piaget, 2002.

NEGRI, Antônio. O Poder Constituinte. Ensaio sobre as Alternativas da Modernidade. Trad. Adriano Pilatti. Rio de Janeiro: DP\&A, 2002.

OLIVEIRA, Paulo Henrique Blair de. Discutindo o essencial. In: Observatório da Constituição e da Democracia, Brasília, nº 1, 2006.

Petição Inicial dos Democratas. Disponível em: http://redir.stf.jus.br/estfvisualizadorpub/jsp/ consultarprocessoeletronico/ConsultarProcessoEletronico.jsf?seqobjetoincidente=2691269. Acesso em 06.09.2010.

PAIXÃO, Cristiano; BIGLIAZZI, Renato. História Constitucional e Norte-americana: do surgimento à estabilização da forma constitucional. Brasília: Editora UNB, 2008.

PAIXÃO, Cristiano; CARVALHO NETTO, Menelick. Entre Permanência e Mudança: reflexões sobre o conceito de constituição. Carlos Alberto Molinaro; Mariângela Guerreiro Milhoranza; Sérgio Gilberto Porto (Org.). In: Constituição, Jurisdição e Processo - Estudos em Homenagem aos 55 anos da Revista Jurídica. 1. ed., Sapucaia do Sul, RS: Notadez, 2007.

PINTO, Cristiano Paixão Araujo. Modernidade, Tempo e Direito. Belo Horizonte: Del Rey, 2002.

PISCITELLI, Rui Magalhães. O Estado como Promotor de Ações Afirmativas e a Política de Cotas para o Acesso dos Negros à Universidade. Curitiba: Juruá, 2009.

ROSENFELD, Michel. A Identidade do Sujeito Constitucional. Menelick de Carvalho Netto (Trad.). Belo Horizonte: Mandamentos, 2003.

SAMPAIO, Anita Lapa Borges. Autonomia Universitária: um modelo de interpretação do artigo 207 da Constituição Federal. Brasília: Editora da Universidade de Brasília, 1998.

SILVA, José Afonso da. Curso de Direito Constitucional Positivo. São Paulo: Malheiros, 2002.

UNIVERSIDADE FEDERAL DE PERNAMBUCO. Admissão de Alunos. Disponível em: http://www.ufpe.br/proacad/index.php?option=com_content\&view=article\&id=72\&ltemid= 140. 2010. Acesso em 10.07.2010.

UNIVERSIDADE FEDERAL DO TOCANTINS. Vestibular. Disponível em: http://www.copese.uft.edu.br/. 2010. Acesso em 10.07.2010.

WALDRON, Jeremy. One Law for all? The Logic of Cultural Accommodation. In: 59 Washington and Lee Law Review 2002. 